\title{
Harlequin fetus in a twin sibling: a rare case report
}

\author{
Rabia Merve Palalıoğlu (iD, Halil İbrahim Erbıyık² (D), Aytakin Mahammadaliyeva' ${ }^{1}$ (D), \\ Batuhan Palalıoğlu ${ }^{3}$ iD, Rojda Bayar ${ }^{4}$ \\ ${ }^{1}$ Department of Obstetrics and Gynecology, University of Health Sciences Ümraniye Training and Research Hospital, Istanbul, Turkey

 \\ ${ }^{3}$ Department of Pediatrics, University of Health Sciences Ümraniye Training and Research Hospital, Istanbul, Turkey \\ ${ }^{4}$ Department of Midwifery, Faculty of Health Sciences, Aydn Adnan Menderes University, Aydm, Turkey
}

\begin{abstract}
Objective: Ichthyosis is a heterogeneous group of disorders characterized by hereditary keratinization of the skin. There are at least 20 different types of ichthyosis. Among these, Harlequin-type ichthyosis is a rare, but often fatal, special form of congenital ichthyosis. Our main goals in presenting this Harlequin-type ichthyosis case are to emphasize the antenatal diagnosability, avoid complications associated with the disease, indicate the need to initiate timely and appropriate treatment to combat these complications, and emphasize that ichthyosis is rare in twin pregnancies.

Case: We presented an ichthyosis case born from a dizygotic pregnancy of a Syrian woman living as a refugee in Turkey. Despite all the medical procedures performed in the neonatal intensive care unit, the baby who was diagnosed with Harlequin type ichthyosis died on the second postpartum day.

Conclusion: Few cases of ichthyosis in twins have been reported. It is very important to benefit from prenatal screening and genetic counseling in the early diagnosis of such inherited, rare and fatal diseases.
\end{abstract}

Keywords: ABCA12 gene, autosomal recessive, congenital ichthyosis, eclabium, ectropion, Harlequin-type ichthyosis, keratinization disorders, twin pregnancy.

\section{Introduction}

Harlequin-type ichthyosis (HI) is a serious and fatal form of congenital ichthyosis. It is an autosomal recessive genetic disorder that controls the desquamation process in the 2nd chromosome and causes a defect in lipid transport, resulting from a mutation in the adenosine triphos-
Özet: íkizlerin birinde Harlequin tipi fetüs: Nadir bir olgu sunumu

Amaç: İktiyozis, cildin kalıtsal keratinizasyonu ile karakterize olan heterojen bir bozukluk grubudur. En az 20 farklı iktiyozis türü bulunmaktadır. Bunlar arasında, Harlequin tipi iktiyozis nadir fakat sıklıkla ölümcül olan özel bir konjenital iktiyozis formudur. Harlequin tipi iktiyozis olgumuzu sunmaktaki ana amaçlarımız, antenatal tanı konulabilirliği vurgulamak, hastalıkla ilişkili komplikasyonlardan kaçınmak, bu komplikasyonlarla mücadele etmek amacıyla zamanında ve uygun tedaviyi başlatma ihtiyacını ortaya koymak ve iktiyozisin ikiz gebeliklerde nadir olduğunu belirtmektir.

Olgu: Çalışmamızda, Türkiye'de yaşayan Suriyeli bir mülteci kadının dizigotik gebeliğinden doğan bir iktiyozis olgusunu sunduk. Neonatal yoğun bakım ünitesinde gerçekleştirilen tüm tıbbi müdahalelere rağmen, Harlequin tipi iktiyozis tanısı alan bebek ikinci postpartum günde kaybedildi.

Sonuç: İkizlerde az sayıda iktiyozis olgusu bildirilmiștir. Bu tür kalıtsal, nadir ve ölümcül hastaların erken tanısında prenatal tarama ve genetik danışmanlıktan faydalanmak çok önemlidir.

Anahtar sözcükler: ABCA12 geni, otozomal resesif, konjenital iktiyozis, eklabium, ektropion, Harlequin tipi iktiyozis, keratinizasyon bozuklukları, ikiz gebelik.

phate (ATP) binding cassette A12 (ABCA12) gene. ${ }^{[1]}$ Its overall incidence is 1 in 300,000 births. ${ }^{[2]}$ It is the most severe form of congenital ichthyosis characterized by extensive fissure and various degrees of cutaneous malformations. Since the body surface is covered with dense keratinized skin, the protective feature of the skin is impaired

Correspondence: Rabia Merve Palalığlu, MD. Department of Obstetrics and Gynecology, University of Health Sciences Ümraniye Training and Research Hospital, Istanbul, Turkey. e-mail: drmerbiyik@gmail.com / Received: June 21, 2021; Accepted: August 7, 2021

How to cite this article: Palalığlu RM, Erbıyık Hİ, Mahammadaliyeva A, Palalıŏlu B, Bayar R. Harlequin fetus in a twin sibling: a rare case report. Perinatal Journal 2021;29(3):266-269. doi:10.2399/prn.21.0293012

ORCID ID: R. M. Palalığlu 0000-0003-2717-7925; H. İ. Erbıyık 0000-0001-5526-2663; A. Mahammadaliyeva 0000-0002-8801-5607; 
and the tendency to infection increases. Restriction of breathing causes hypoventilation and respiratory failure. Ectropion, eclabium, flattening of the ears, deformity of the fingers and auto amputation, hypo- or hyperthermia, electrolyte imbalances, severe skin and lung infections are among the causes of death in the first days of life. ${ }^{[1,3]}$ The survival rate is inversely proportional to the severity of the disease. ${ }^{[4]}$ Today, the life expectancy and quality of these babies are extended in neonatal intensive care units, primarily with retinoid treatments. ${ }^{[5]}$ Our main goals in presenting this case are to emphasize the antenatal diagnosability, avoid complications associated with the disease, indicate the need to initiate timely and appropriate treatment to combat these complications, and emphasize that ichthyosis is rare in twin pregnancies. Patient written consent was obtained for all the results of the mother and baby to be used in this case report.

\section{Case Report}

A 27 -year-old patient with gravida 5, para 3, and a twin pregnancy at 33 weeks of gestation was admitted to our University of Health Sciences Ümraniye Training and Research Hospital emergency gynecology unit at 10:10 a.m. on 05.28.2020 with the complaint of "pain". It was learned that the patient had no antenatal follow-up, and no ultrasonography was performed. Previous deliveries were performed by normal vaginal route. In vaginal examination, the cervix was dilated $7-8 \mathrm{~cm}, 60 \%$ effaced, and the pouch was intact. Ultrasound scan revealed that fetus 1 was positioned head-first and fetus 2 anus-first. The patient, who was admitted to the delivery room, was strained simultaneously with contractions. Spontaneous vaginal delivery was performed at 10:20 a.m. within 7 minutes. The first baby was delivered head-first. The premature baby had an appearance, pulse, grimace, activity, and respiration (Apgar) score of 4-5; sex was female, and her weight was $1430 \mathrm{~g}$. She did not cry immediately at birth and spontaneous breathing did not occur. Physical examination revealed adherent vernix on the baby's face, ears, and neck and a large skin thickening with a common collodion-like coating over the whole body. This thickening was split into deep fissures, and skin peeling (Fig. 1). A typical appearance resembling a clown smile on the face (Fig. 2), erosion on the nasal cartilage, nasal hypoplasia, and open-mouth findings were present. Hyperkeratosis pattern, hypoplastic ear, contracture and deformation findings in the fingers and toes, and rudimentary appearance in the urogenital region were observed. With these findings, the patient was diagnosed with Harlequin-type ichthyosis and was intubated in the delivery room. The second baby was delivered foot-first at 10:23 a.m. APGAR score was 4-6; sex was male; weight was $1620 \mathrm{~g}$. No congenital anomaly was found in the 2 nd baby (as observed in the 1st baby). Both babies were taken to the neonatal intensive care unit.

During the period of hospitalization in the intensive care unit, the baby with HI was started on intravenous fluid prevent dehydration and fed with parenteral nutrition. The baby was wrapped in sterile covers to avoid infection. The skin was dressed with moisturizers and antibiotic ointments, and debridement was performed. However, the first baby whose general condition worsened despite the treatments died from sepsis and respiratory failure 2 days after birth. In the puerperal examination of the mother, her general condition was good, vitals stable, and uterus contracted. Further, the endometrial cavity was observed as regular in the control ultrasonographic examination. In her vaginal examination, no episiotomy or dehiscence was observed. Lochia rubra was natural in appearance. The follow-up of the mother was resumed in the service, and the care process continued. Postpartum discharge training was given by doctors and midwives 24 hours after birth. Gynecological emergencies were explained, and the mother was discharged. The study's registration / ethics committee approval was unnecessary due to the nature of the study.

\section{Discussion}

Harlequin-type ichthyosis, also known as congenital ichthyosis or keratosis diffusa fetalis, is a very rare genetic disorder that develops as a result of a mutation of the gene ABCA12, which causes defect in the lipid transport, and results in the thickening of keratin layer of the skin (hyperkeratosis A) ${ }^{[1]}$ The first Harlequin case was reported in 1750 , and it started to be diagnosed antenatally in $1983 .^{[6,7]}$ Approximately 200 cases have been reported worldwide. ${ }^{[8]}$ The pattern of autosomal recessive inheritance indicating the role of kinship among parents is a contributing factor. Perinatal diagnosis is important for the early diagnosis of the disease. Among the sonographic findings used in the prenatal diagnosis of Harlequin ichthyosis, there are severe deformity of the eyelids and protrusion of the conjunctiva, excessive edema in the extremities, IUGR, polyhydramnios, cracks and clefts in the skin, short fingers, flat nose, constantly open mouth, undeveloped flat outer ears. However, in our case, sonographic imaging could not be obtained because there was 


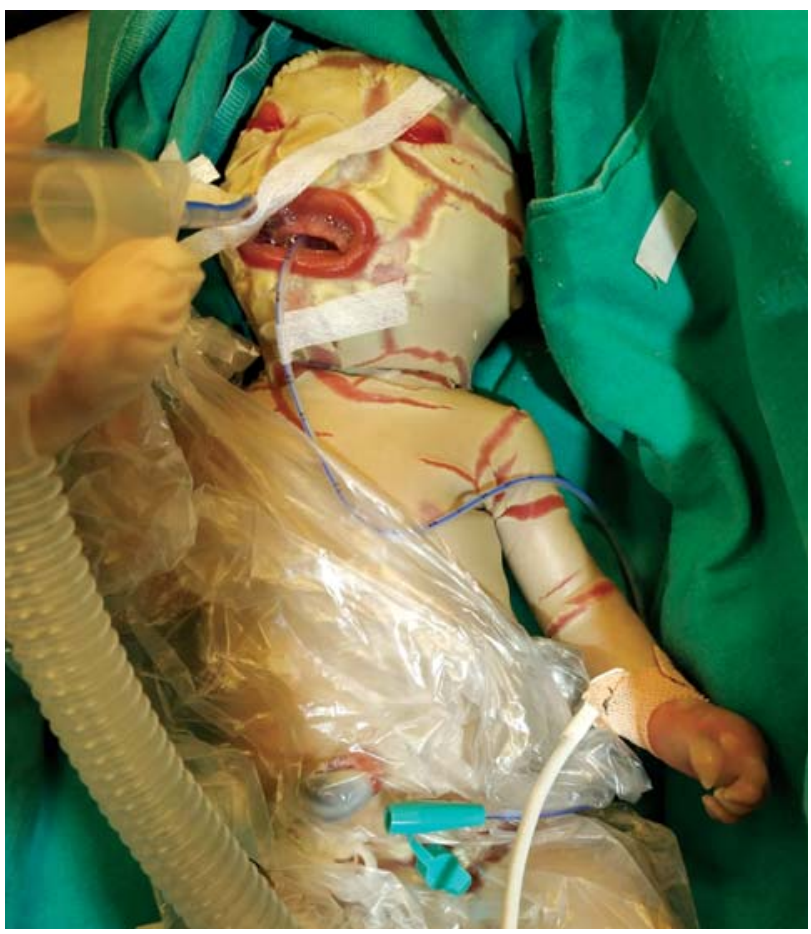

Fig. 1. Physical examination revealed adherent vernix on the baby's face, ears, and neck and a large skin thickening with a common collodion-like coating over the whole body. This thickening was split into deep fissures, and skin peeling.

no antenatal follow-up. ${ }^{[7]}$ Chorionic villus sampling or amniocentesis (fetal DNA) is recommended for suspected cases during examinations and also for women with previously affected babies. Skin biopsy is not currently recommended for prenatal diagnosis. ${ }^{[9]}$ In addition, it is important to ask for a detailed description of family history, kinship among parents, information about previous pregnancies, and whether other children have any inherent dermatological conditions. Our case could not be evaluated in terms of diagnosis in the perinatal period because she was a Syrian pregnant woman without follow-up and without any antenatal screening. The diagnosis was made by the characteristic rough physical appearance of the baby after birth. Babies with $\mathrm{HI}$ are usually born prematurely. This means that the prematurity complications will also tend to evolve. Patients with $\mathrm{HI}$ should be followed up in fully equipped intensive care units with a multidisciplinary approach. Moisturizing the skin frequently in order to prevent fluid loss, using incubators with humidity adjustments, compliance with hygiene standards, appropriate fluid treatment, maintaining heat balance, and protection from infection are the



Fig. 2. A typical appearance resembling a clown smile on the face, erosion on the nasal cartilage, nasal hypoplasia, and openmouth findings were present.

main factors to be considered in the treatment. The skin needs softening due to its structure. Because of the high loss of water that occurs in the cases of this disease, dryness causes the skin to stretch and harden like an armor. Mucosal surface and visceral organs are usually preserved. ${ }^{[10]}$ In the present case, the baby affected by the disease was born prematurely and had typical HI symptoms. $\mathrm{HI}$ mortality rate is $75 \%,{ }^{[4]}$ and most babies die in the first days of life due to secondary complications such as severe fluid loss, deterioration in heat balance, infection, and dehydration. ${ }^{[11]}$ In the present case, the baby died due to similar reasons. Cases of ichthyosis developing in twin pregnancies are rarely encountered in the literature, and it is rarely seen that one baby is healthy while the other has ichthyosis. Very few cases have been reported with a similar result to our case. ${ }^{[12]}$ However, the chances of survival of fetuses with this condition are known to be related to the type of mutation. Babies with compound heterozygous mutations survive more than those with homozygous mutations. ${ }^{[1,13]}$ Postpartum treatments and care improve the prognosis of the disease. In our case, the pathological examination of the baby could not be per- 
formed as we could not obtain the parents' consent. With supportive care, the quality of life of babies improves, and the survival rate rises $>50 \%$. In addition to routine care such as controlling the vital signs, babies with $\mathrm{HI}$ must be kept in a warm and humid incubator, and their hydration must be maintained. Parents could be informed about the possible damages of consanguineous marriages through genetic counseling. It also enables early prenatal evaluation and diagnosis. Families may be offered the option of termination. In terms of reducing the problems and maintaining the quality of care, it is important that physicians and midwives who work in primary care provide necessary pre-marital counseling to families. ${ }^{[1,15]}$ In our case, the fact that the patient was not followed up and did not benefit from any counseling service supports the results of this case.

\section{Conclusion}

Prenatal diagnosis is very important in genetically transmitted fatal diseases. Diagnosis of $\mathrm{HI}$ in the prenatal period is easy with ultrasonographic examination and ABCA12 gene mutation screening. Thus, the termination option will be possible. Genetic counseling is very important for families with consanguineous marriages who give a history of infants with $\mathrm{HI}$ for this serious disease that cannot be prevented and has no definitive treatment.

Funding: This work did not receive any specific grant from funding agencies in the public, commercial, or not-for-profit sectors.

Compliance with Ethical Standards: The authors stated that the standards regarding research and publication ethics, the Personal Data Protection Law and the copyright regulations applicable to intellectual and artistic works are complied with and there is no conflict of interest.

\section{References}

1. Hovnanian A. Harlequin ichthyosis unmasked: a defect of lipid transport. J Clin Invest 2005;115:1708-10. [PubMed] [CrossRef]

2. Glick JB, Craiglow BG, Choate KA, Kato H, Fleming RE, Siegfried E, et al. Improved management of Harlequin ichthyosis with advances in neonatal intensive care. Pediatrics 2017;139:e20161003. [PubMed] [CrossRef]

3. Kelsell DP, Norgett EE, Unsworth H, Teh MT, Cullup T, Mein CA, et al. Mutations in ABCA12 underlie the severe congenital skin disease Harlequin ichthyosis. Am J Hum Genet 2005;76:794-803. [PubMed] [CrossRef]

4. Rajpopat S, Moss C, Mellerio J, Vahlquist A, Gånemo A, Hellstrom-Pigg $M$, et al. Harlequin ichthyosis: a review of clinical and molecular findings in 45 cases. Arch Dermatol 2011;147:681-6. [PubMed] [CrossRef]

5. Chang LM, Reyes M. A case of harlequin ichthyosis treated with isotretinoin. Dermatol Online J 2014;20(2):doj_21540. [PubMed] [CrossRef]

6. Ukkali S, Patil V, Rajgoli EA, Kutty JM, Desai MZ. Harlequin ichthyosis: a case report. Journal of Evolution of Medical and Dental Sciences 2015;4(91):15700-2. [CrossRef]

7. Bongain A, Benoit B, Ejnes L, Lambert JC, Gillet JY. Harlequin fetus: three-dimensional sonographic findings and new diagnostic approach. Ultrasound Obstet Gynecol 2002;20: 82-5. [PubMed] [CrossRef]

8. Baby C. Harlequin ichthyosis: a disease chronic rather than fatal. World Journal of Pharmacy and Pharmaceutical Sciences 2016;5:1957-66. [CrossRef]

9. Aggarwal S, Kar A, Bland P, Kelsell D, Dalal A. Novel ABCA12 mutations in harlequin ichthyosis: a journey from photo diagnosis to prenatal diagnosis. Gene 2015;556:254-6. [PubMed] [CrossRef]

10. Pandey R. Congenital icthyosis: a case report. Clin Res Trials 2017;3:1-3.[CrossRef]

11. Akiyama M. The pathogenesis of severe congenital ichthyosis of the neonate. J Dermatol Sci 1999;21:96-104. [PubMed] [CrossRef]

12. Bari AU, Najmi S. Harlequin fetus in a twin pregnancy: an extremely rare presentation. J Coll Physicians Surg Pak 2020;30:652-4. [PubMed] [CrossRef]

13. Akiyama M, Sugiyama-Nakagiri Y, Sakai K, McMillan JR, Goto $\mathrm{M}$, Arita K, et al. Mutations in lipid transporter ABCA12 in harlequin ichthyosis and functional recovery by corrective gene transfer. J Clin Invest 2005;115:1777-84. [PubMed] [CrossRef]

14. Novick G. Women's experience of prenatal care: an integrative review. J Midwifery Womens Health 2009;54:226-37. [PubMed] [CrossRef]

15. Gonzalez-Guarda RM, McCabe BE, Mathurin E, DeBastiani SD, Peragallo Montano N. The influence of relationship power and partner communication on the syndemic factor among Hispanic Women. Women's Health Issues 2017;27: 478-84. [PubMed] [CrossRef] 